\title{
The influence of sediment properties and experimental variables on the efficiency of electrodialytic removal of metals from sediment
}

\author{
Kristine B. Pedersen*a,b, Tore Lejon ${ }^{a}$, Pernille E. Jensenc and Lisbeth M. Ottosen ${ }^{c}$ \\ *Corresponding author: e-mail kbo@akvaplan.niva.no; tel. +47928 79928 \\ a Department of Chemistry, UiT - The Arctic University of Norway, Postbox 6050 Langnes, N- \\ 9037 Troms $\varnothing$, Norway.
}

b Akvaplan-niva AS, Fram Centre - High North Research Centre for Climate and the Environment, Hjalmar Johansens gate 14, 9007 Troms $\varnothing$, Norway (present address)

${ }^{c}$ Arctic Technology Centre, Department of Civil Engineering, Technical University of Denmark, Building 118, 2800 Lyngby, Denmark

\begin{abstract}
Chemometrics was used to determine the influence of sediment properties and experimental settings for the electrodialytic removal (EDR) of $\mathrm{Cu}, \mathrm{Pb}$ and $\mathrm{Zn}$ from six harbour sediments from Greenland and Norway. A Projection onto latent structures (PLS) model revealed that the most important sediment properties for achieving acidification (lag-phase, $\mathrm{pH}>4$ ), necessary for desorbing and mobilising metals in the polluted sediments, were buffer capacity and grain size distribution. Higher stirring rate reduced the acidification time, stressing the importance of thorough mixing of the sediment suspension to achieve a fast and uniform acidification.
\end{abstract}

PLS models were calculated to determine the influence of sediment properties on the removal of metals during EDR, which was observed to vary depending on the targeted metal and the stage of the remediation. In general, buffer capacity, grain size distribution, element composition and metal partitioning were important for remediation efficiency and are important parameters for determining

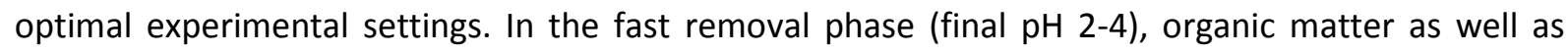
stirring rate had increasing importance indicating oxidation and release of metals at this stage. Understanding the influence of sediment properties is important for determining experimental settings in accordance with the phase of EDR.

Keywords: Chemometrics, PLS, EDR, EKR, heavy metals, sediments

\section{Introduction}

The need for remediating harbour sediments arises either through development of harbours in which contact with, or removal of polluted sediments is inevitable, e.g. when increasing navigational depths, or due to governmental acts to decrease the adverse effects on the marine environment and human 
health. The choice of remediation technology in a given situation depends on sediment properties, pollutant composition and quantity, as well as cost-effectiveness and site specific conditions. Understanding the influence of sediment properties on the efficiency of the remediation is vital for ensuring optimal settings and adjustments during the different stages of a remediation.

Multivariate analysis provides tools for analysing large sets of data, which is done by reducing the dimensions making it easier to visualise and retrieve trends. One such tool is projections onto latent structures (PLS) in which optimum settings for independent as well as correlated variables are determined and can for instance be used to evaluate the comparative importance of sediment properties on remediation processes. In remediation, sediment properties and experimental variables cannot necessarily be assumed to be independent; unlike some of the more traditional statistical analyses such as multiple regression PLS copes with collinearity between variables [1]. Other advantages of PLS is that it provides plots of the data compressed to fewer dimensions than the original dataset, easing the interpretation, it copes with noise in both the $X$ and $Y$ matrices and moderate amounts of missing data [2-4].

PLS and other multivariate methods, such as fractional factorial designs and principal component analysis, have been extensively used for optimisation in organic synthesis, the method has found limited use in pollution studies. It has however been employed for identifying important factors for formation of toxic PCB during waste combustion [5] and to assess the influence of soil properties on the chemical oxidation of PAH in soil [6]. In addition, our group has previously demonstrated the use of PLS models for evaluating the experimental variables for sediment-specific electrodialytic remediation (EDR) [7-10], as well as a tool for predicting experimental settings in new sediment [11].

EDR is a method originally developed for removing heavy metals from soil in the 1990s [12]. The method has since been developed for efficiently removing heavy metals from other polluted materials such as wood, fly ash, sewage sludge and harbour sediments [13-16]. EDR is based on the principles of electrokinetic remediation (EKR) in which an electric field of low current density is applied to the polluted material, initiating acidification processes and subsequent desorption of heavy metals. Transport processes are dominated by electromigration, i.e. the transport of ions and ionic complexes in the pore fluid of the polluted material [17-19].

The removal of metals in soils during EDR can roughly be divided into three phases [20];

1. Lag phase (acidification) in which pH decreases to the threshold value of initiating desorption of the specific metal. During this phase the metal removal is limited.

2. Fast removal phase in which rapid dissolution/desorption of the specific metal in the available fractions of the sediment occurs.

3. Slow removal phase in which a continuous dissolution/desorption of the specific metal in the lesser available fractions of the sediment occurs.

The duration of each phase and the metal removal rate depends on the sediment properties and also reflects how the metal is bound in the sediment [17, 19, 21-23]. The removal rate of Ca was for instance found to be much faster than the other investigated metals (Al, Fe, K, Mg, Mn and Pb) [20]. Sediment properties reported to prolong acidification in both EDR and EKR include high contents of carbonate, organic matter and salts $[17,19,21,22,24]$ contributing to the buffer capacity of the soil/sediment. Other sediment properties reported to affect the efficiency of EDR are grain size and 
concentration/composition of metals. Removal of metal is faster from soil fines $(<63 \mu m)[25,26]$ due to the electric field being more being a more effective driving force for transport of fluid in fine-grained soils of low hydraulic conductivity than a hydraulic gradient. Studies summarised in [27] found that the composition and concentration of elements in the soil resulted in lower removal rates of each individual metal. This is related to transport under the influence of an electric field, when the concentration of a given metal decreases, relative to other metals present, the ion migration of the specific metal will be less efficient [17].

Current density and time have been shown to be the most important experimental variables influencing EDR [16, 25, 28-30]. High current densities may however impede the removal and increase the energy consumption significantly. The limiting current densities have been reported to depend on the soil/sediment properties. Stirring significantly improves removal efficiencies $[14,29,31]$ and a high stirring rate could increase the removal of metals, for instance metals found in the organic fraction of the soil/sediments can be mobilised by oxidation of the sediment [29]. The liquid-solid (L/S) ratio of the sediment suspension may to a lesser extent influence removal efficiencies in EDR [25, 26, 32].

Sediment properties have been shown to affect the efficiency of EDR, however assessing the relative influence and scrutinising the influence in the different phases of EDR has yet to be undertaken. The focus of this study is to assess the comparative influence of sediment properties and experimental variables in the three phases of EDR. This is done through multivariate analysis of previously reported results, supplemented with additional experiments of six different sediments. The influence of sediment properties on the EDR process parameters acidification time and energy consumption has also been evaluated.

\section{Methods and materials}

\subsection{Experimental sediments}

Sediments from Sisimiut, Greenland and Hammerfest, Norway were sampled from the top $10 \mathrm{~cm}$ of the seabed using a Van Veen grab and were kept frozen during transport and stored in a freezer until analysed or treated.

\subsection{Sediment analyses}

The six sediments were analysed for $\mathrm{pH}$, electric conductivity, cation exchange capacity (CEC), grain size analysis and content of elements ( $\mathrm{Al}, \mathrm{Ca}, \mathrm{Fe}, \mathrm{K}, \mathrm{Mg}, \mathrm{Mn}, \mathrm{Na}, \mathrm{Cr}, \mathrm{Cu}, \mathrm{Ni}, \mathrm{Pb}, \mathrm{Zn}$ ), chloride, total carbon, sulphur, nitrogen, phosphorous, carbonate and organic matter. The results of these are summarised in table 1 and the description of methods and materials for these analysis are described in detail in [33]. In this study, the sediment characteristics were supplemented with metal desorption experiments to evaluate the availability of metals in the sediment.

Table 1: Sediment characteristics (6 sediments) from Hammerfest (H1, H3, H4 and H5) and Sisimiut (S1 and S2). A summary of the results were previously reported in [33] and the original sediment id have been kept.

\begin{tabular}{|l|l|l|l|l|l|l|l|}
\hline Characteristic & Units & H1 & H3 & H4 & H5 & S1 & S2 \\
\hline Carbonate & $\%$ & 45 & 8.8 & 0.7 & 0.7 & 0.7 & 1.7 \\
\hline Organic matter & $\%$ & 5.4 & 4.8 & 14.7 & 5.3 & 8.5 & 6.4 \\
\hline Total carbon & $\%$ & 7.3 & 3.3 & 10.1 & 3.1 & 5.3 & 3.2 \\
\hline Sulphur & $\%$ & 0.3 & 0.2 & 1.2 & 0.3 & 0.8 & 0.7 \\
\hline Nitrogen & $\%$ & 0.5 & 0.1 & 0.1 & 0.01 & 0.5 & 0.3 \\
\hline
\end{tabular}




\begin{tabular}{|c|c|c|c|c|c|c|c|}
\hline $\mathrm{pH}$ & & 8.1 & 8.2 & 7.0 & 7.5 & 7.0 & 7.5 \\
\hline Conductivity & $\mathrm{mS} / \mathrm{cm}$ & 8.7 & 9.1 & 20.0 & 12.3 & 7.5 & 8.8 \\
\hline Grain size & & & & & & & \\
\hline Clay $(<2 \mu m)$ & & 6.3 & 5.7 & 8.9 & 4.3 & 8.8 & 1.6 \\
\hline Silt $(2-63 \mu \mathrm{m})$ & $\%$ & 22 & 38 & 32 & 18 & 52 & 20 \\
\hline Sand $(63-200 \mu \mathrm{m})$ & & 68 & 56 & 54 & 77 & 38 & 76 \\
\hline Gravel (>200 $\mu \mathrm{m})$ & & 3.7 & 0.3 & 5.1 & 0.7 & 1.2 & 2.4 \\
\hline CEC & $\mathrm{meq} / 100 \mathrm{~g}$ & 8.0 & 2.5 & 12.8 & 2.4 & 4.3 & 1.8 \\
\hline Chloride & \multirow{17}{*}{$\mathrm{mg} / \mathrm{kg}$} & 7990 & 7780 & 14100 & 9200 & 6240 & 7950 \\
\hline$P$ & & 645 & 1450 & 3100 & 800 & 1800 & 1870 \\
\hline $\mathrm{Al}$ & & 3700 & 8650 & 8050 & 6700 & 6650 & 4250 \\
\hline $\mathrm{Ba}$ & & 1350 & 137 & 370 & 121 & 159 & 100 \\
\hline $\mathrm{Ca}$ & & 1456000 & 28100 & 8800 & 4500 & 7100 & 6000 \\
\hline $\mathrm{Fe}$ & & 6400 & 15200 & 18700 & 11200 & 14500 & 10100 \\
\hline $\mathrm{K}$ & & 1700 & 4440 & 3500 & 2800 & 2300 & 1450 \\
\hline $\mathrm{Mg}$ & & 7560 & 5500 & 6750 & 4650 & 6000 & 3450 \\
\hline $\mathrm{Mn}$ & & 97 & 132 & 123 & 118 & 112 & 69 \\
\hline $\mathrm{Na}$ & & 6850 & 3750 & 15500 & 4500 & 7200 & 4600 \\
\hline $\mathrm{V}$ & & 25 & 50 & 77 & 44 & 69 & 35 \\
\hline $\mathrm{Cd}$ & & 0.1 & 0.3 & 1.1 & 0.1 & 0.5 & 0.4 \\
\hline $\mathrm{Cr}$ & & 15 & 23 & 47 & 24 & 37 & 25 \\
\hline $\mathrm{Cu}$ & & 116 & 54 & 167 & 47 & 216 & 184 \\
\hline $\mathrm{Ni}$ & & 10 & 15 & 23 & 15 & 18 & 18 \\
\hline $\mathrm{Pb}$ & & 49 & 46 & 152 & 42 & 73 & 57 \\
\hline $\mathrm{Zn}$ & & 83 & 140 & 540 & 94 & 340 & 960 \\
\hline
\end{tabular}

Sequential extraction was made in four steps based on the extension of the three-step method described by Standards, Measurements and Testing Program of the European Union [34]. Air-dried sediment $(0.5 \mathrm{~g})$ was first extracted with acetic acid $(0.11 \mathrm{M}, 20 \mathrm{~mL}, \mathrm{pH} 3)$ for 16 hours; secondly with hydroxylammonium chloride $(0.1 \mathrm{M}, 20 \mathrm{~mL}$; $\mathrm{pH} 2)$ for 16 hours; thirdly with hydrogen peroxide $(8.8 \mathrm{M}$, $5 \mathrm{~mL}$ ) for 1 hour, followed by extraction at $85{ }^{\circ} \mathrm{C}$ for 1 hour, evaporation of liquid at $85{ }^{\circ} \mathrm{C}$, and subsequent extraction of the cooled solid fraction with ammonium acetate $(1 \mathrm{M}, 25 \mathrm{~mL}, \mathrm{pH} 2)$ for $16 \mathrm{~h}$; and fourthly the remaining solid particles were analysed for metal content after digestion. The solids and HNO3 $\left(9 \mathrm{M}, 20 \mathrm{~mL}\right.$ ) were autoclaved $\left(200 \mathrm{kPa}, 120{ }^{\circ} \mathrm{C}, 30\right.$ minutes). Solid particles were subsequently removed by vacuum filtration through a $0.45 \mu \mathrm{m}$ filter and the liquid was diluted to $100 \mathrm{~mL}$. Metal concentrations in the liquid were measured by Inductively Coupled Plasma - Optical Emission Spectrometry (ICP-OES) on a Varian 720-ES in the Arctic Technology Centre at The Technical University of Denmark.

Desorption of metals as function of $\mathrm{pH}$ were made by agitating 10 samples of dried sediment $(5 \mathrm{~g})$ with $\mathrm{HNO}_{3}(25 \mathrm{~mL})$ in varying concentrations $(0.01,0.05,0.1,0.5$ and $1.0 \mathrm{M})$. Two extractions in distilled water were made as reference. The suspensions were agitated for a week on a horizontal shaker. Subsequently samples settled for $15 \mathrm{~min}$ and the $\mathrm{pH}$ was measured using a radiometric analytical electrode and the measuring instrument SenION+ MM374. The sediment suspensions were vacuum filtered through a $45 \mu \mathrm{m}$ filter. Metal concentrations in the liquid and solid particle fractions (after digestion) were measured by ICP-OES to determine the percentage of metals desorbed (liquid fraction).

\subsection{EDR experiments}

\subsubsection{Materials}


In all of the experiments a 3-compartment electrodialytic cell design was used and an illustration of the set-up can be found elsewhere [30]. The experimental set-up consisted of a centre compartment containing the sediment suspensions and electrolyte liquids were circulated in two adjoining compartments. The set-up was designed in a way that exploited water splitting at the anion exchange membrane to ensure acidifying conditions in the sediment suspension. Application of ion exchange membranes controlled the transport of ions between the electrolyte compartments and the sediment suspension compartment, thus preventing protons and hydroxyl ions from electrolysis reactions at the electrodes, from entering the sediment suspension compartment.

The electrodialytic cell was manufactured from Plexiglas. The length of the centre compartment was $10 \mathrm{~cm}$, the length of each electrolyte compartment was $3.5 \mathrm{~cm}$ and all three compartments had an inner diameter of $8 \mathrm{~cm}$. The choice of membranes in this study was based on functionality in the $\mathrm{pH}$ range 1-8. For further reference to the influence of membranes on the performance during electrodialytic treatment, the reader is referred to [35]. Ion exchange membranes from lonics (anion exchange membrane 204 SZRA B02249C and cation exchange membrane CR67 HUY N12116B) separated the electrolyte compartments from the polluted sediment compartment. $\mathrm{NaNO}_{3}(0.01 \mathrm{M})$ was used as electrolyte liquids and was continuously adjusted to $\mathrm{pH} 2$ by $\mathrm{HNO}_{3}(5 \mathrm{M})$. The electrolytes $(300 \mathrm{ml})$ were circulated via an Ismatec reglo pump with a flow rate of $10 \mathrm{ml} / \mathrm{min}$. Platinum coated titanium electrodes were used in each electrolyte compartment and a power supply (Hewlett Packard E3612A) maintained a constant DC current. The sediment suspension was stirred by a CAT R14 motor with a stirrer consisting of plastic flaps $(4 \mathrm{~cm} \times 0.5 \mathrm{~cm})$ fastened to a glass rod.

After the EDR experiments sediments were filtered through a Whatman CAT 1113-320 filter $(32.0 \mathrm{~cm})$ and the metal concentrations in both the suspension liquid and solids were measured. The stirrer, membranes and electrodes were soaked in $\mathrm{HNO}_{3}(5 \mathrm{M})$ overnight and the heavy metal concentrations in the soaking liquids as well as the electrolyte liquids were measured by ICP-OES.

\subsubsection{Experimental design}

A total of 47 experiments were used in this study, of which 43 were conducted in connection with other studies with different study objectives and were all based on fractional factorial designs. The experiments do not cover a perfect multivariate design, none the less, as is apparent from table 2, similar experimental domains were applied. The current density refers to current across the membrane, i.e the current per membrane area covering the inner circumference of the electrodialytic cell:

Current density $=$ Current $(\mathrm{mA}) /$ Area of inner circumference of electrodialytic cell $\left(\mathrm{cm}^{2}\right)$

Table 2: The experimental settings of the experiments used in multivariate analysis for assessing influence of sediment properties.

\begin{tabular}{|c|c|c|c|c|c|c|c|c|}
\hline Experiment & Sediment & $\begin{array}{l}\text { Time } \\
\text { (h) }\end{array}$ & $\begin{array}{l}\text { Time after } \\
\text { acidification } \\
\text { (h) }\end{array}$ & $\begin{array}{l}\text { Current } \\
\text { density } \\
\left(\mathrm{mA} / \mathrm{cm}^{2}\right)\end{array}$ & $\begin{array}{l}L / S \\
(\mathrm{ml} / \mathrm{g})\end{array}$ & $\begin{array}{l}\text { Stirring } \\
\text { rate } \\
\text { (rpm) }\end{array}$ & $\begin{array}{l}\text { Suspension } \\
\text { liquid }\end{array}$ & $\begin{array}{l}\text { Light/no } \\
\text { light }\end{array}$ \\
\hline 1 & $\mathrm{H} 1$ & 332 & 0 & 0.2 & 2 & 1300 & Distilled water & Light \\
\hline 2 & $\mathrm{H} 1$ & 163 & 0 & 0.2 & 2 & 1300 & Distilled water & Light \\
\hline $3^{1}$ & $\mathrm{H} 3$ & 672 & 0 & 0.04 & 12 & 1 & Distilled water & Light \\
\hline $4^{1}$ & $\mathrm{H} 3$ & 672 & 296 & 0.8 & 2 & 1 & Tap water & Light \\
\hline $5^{1}$ & $\mathrm{H} 3$ & 192 & 0 & 0.04 & 2 & 1300 & Tap water & Light \\
\hline $6^{1}$ & $\mathrm{H3}$ & 672 & 0 & 0.04 & 2 & 1 & Tap water & No light \\
\hline
\end{tabular}




\begin{tabular}{|c|c|c|c|c|c|c|c|c|}
\hline $7^{1}$ & H3 & 192 & 0 & 0.8 & 2 & 1 & Distilled water & Light \\
\hline $8^{1}$ & $\mathrm{H} 3$ & 714 & 490 & 0.8 & 2 & 1300 & Distilled water & No light \\
\hline $9^{1}$ & $\mathrm{H} 3$ & 192 & 0 & 0.04 & 12 & 1300 & Distilled water & No light \\
\hline $10^{1}$ & $\mathrm{H} 3$ & 192 & 50 & 0.36 & 12 & 1 & Distilled water & No light \\
\hline $11^{1}$ & $\mathrm{H} 3$ & 672 & 572 & 0.36 & 12 & 1300 & Tap water & Light \\
\hline $12^{1}$ & $\mathrm{H3}$ & 432 & 295 & 0.42 & 7 & 650 & Distilled water & Light \\
\hline $13^{1}$ & $\mathrm{H} 3$ & 312 & 175 & 0.36 & 7 & 650 & Distilled water & Light \\
\hline $14^{1}$ & $\mathrm{H} 3$ & 312 & 175 & 0.36 & 7 & 650 & Distilled water & No light \\
\hline $15^{1}$ & $\mathrm{H} 3$ & 520 & 383 & 0.36 & 7 & 650 & Distilled water & No light \\
\hline $16^{1}$ & $\mathrm{H3}$ & 307 & 85 & 0.8 & 2 & 1300 & Distilled water & Light \\
\hline $17^{1}$ & $\mathrm{H3}$ & 308 & 85 & 0.68 & 2 & 1300 & Distilled water & Light \\
\hline 18 & $\mathrm{H} 4$ & 332 & 192 & 0.2 & 3 & 1300 & Distilled water & Light \\
\hline 19 & $\mathrm{H} 4$ & 163 & 0 & 0.2 & 3 & 1300 & Distilled water & Light \\
\hline $20^{2}$ & $\mathrm{H} 4$ & 484,5 & 444 & 0.2 & 4 & 1300 & Distilled water & No light \\
\hline $21^{2}$ & $\mathrm{H} 4$ & 517,5 & 444 & 0.52 & 2 & 1300 & Distilled water & Light \\
\hline $22^{2}$ & $\mathrm{H} 4$ & 236,5 & 48 & 0.2 & 2 & 100 & Distilled water & Light \\
\hline $23^{2}$ & $\mathrm{H} 4$ & 88,5 & 48 & 0.52 & 4 & 100 & Distilled water & No light \\
\hline $24^{3}$ & $\mathrm{H} 5$ & 474 & 444 & 0.2 & 6 & 1300 & Distilled water & Light \\
\hline $25^{3}$ & $\mathrm{H} 5$ & 163 & 133 & 0.2 & 6 & 1300 & Distilled water & Light \\
\hline $26^{3}$ & $\mathrm{H} 5$ & 307,5 & 278 & 0.2 & 6 & 1300 & Distilled water & Light \\
\hline $27^{4}$ & $\mathrm{H} 5$ & 25 & 0 & 0.2 & 6 & 1300 & Distilled water & Light \\
\hline $28^{4}$ & $\mathrm{H} 5$ & 81 & 48 & 0.04 & 6 & 1300 & Distilled water & Light \\
\hline $29^{4}$ & $\mathrm{H} 5$ & 51 & 24 & 0.12 & 6 & 1300 & Distilled water & Light \\
\hline $30^{5}$ & $\mathrm{H} 5$ & 307 & 278 & 0.36 & 6 & 1300 & Distilled water & Light \\
\hline $31^{5}$ & $\mathrm{H} 5$ & 190 & 163 & 0.28 & 6 & 1300 & Distilled water & Light \\
\hline $32^{5}$ & $\mathrm{H} 5$ & 75 & 48 & 0.52 & 6 & 1300 & Distilled water & Light \\
\hline $33^{5}$ & $\mathrm{H} 5$ & 190 & 163 & 0.28 & 6 & 1300 & Distilled water & Light \\
\hline $34^{4}$ & $\mathrm{H} 5$ & 184,5 & 163 & 0.12 & 6 & 1300 & Distilled water & Light \\
\hline $35^{4}$ & $\mathrm{H} 5$ & 478 & 446 & 0.52 & 6 & 1300 & Distilled water & Light \\
\hline $36^{3}$ & S1 & 95,5 & 48 & 50 & 4 & 100 & Distilled water & No light \\
\hline $37^{3}$ & S1 & 548 & 444 & 50 & 2 & 1300 & Distilled water & Light \\
\hline $38^{6}$ & S2 & 138,5 & 48 & 0.04 & 2 & 1300 & Tap water & Light \\
\hline $39^{6}$ & S2 & 465,5 & 444 & 0.04 & 12 & 100 & Distilled water & Light \\
\hline $40^{6}$ & S2 & 67,5 & 48 & 1 & 12 & 1300 & Distilled water & No light \\
\hline $41^{6}$ & S2 & 503,5 & 444 & 1 & 2 & 100 & Tap water & No light \\
\hline $42^{6}$ & S2 & 257,5 & 246 & 0.52 & 7 & 700 & Distilled water & Light \\
\hline $43^{6}$ & S2 & 261,5 & 246 & 0.52 & 7 & 700 & Distilled water & Light \\
\hline $44^{6}$ & S2 & 287 & 278 & 0.04 & 6 & 1300 & Distilled water & Light \\
\hline $45^{6}$ & S2 & 71 & 48 & 0.2 & 6 & 1300 & Distilled water & Light \\
\hline $46^{6}$ & S2 & 191,5 & 165 & 0.12 & 6 & 1300 & Distilled water & Light \\
\hline $47^{6}$ & S2 & 189,5 & 163,5 & 0.12 & 6 & 1300 & Distilled water & Light \\
\hline
\end{tabular}

${ }^{1}$ Experiments previously reported in [30]

2 Experiments previously reported in [8]

${ }^{3}$ Experiments previously reported in [11]

${ }^{4}$ Experiments previously reported in [10]

${ }^{5}$ Experiments previously reported in [9]

${ }^{6}$ Experiments previously reported in [7]

The power consumption in Wh (E) was calculated as:

$\int_{t=0}^{t} E=V I d t$

where $\mathrm{V}$ is the voltage between the electrodes $(\mathrm{V}), \mathrm{I}$ is the current $(\mathrm{A})$ and $\mathrm{t}$ is the remediation time $(\mathrm{h})$.

\subsection{PLS modelling}


In PLS, quantitative relations between a descriptor matrix, $\mathrm{X}$, and a response matrix, $\mathrm{Y}$, are calculated based on projections. Object points in each of the $X$ and $Y$ matrices are projected down to a PLS component representing the maximum correlation between the PLS scores of the $\mathrm{Y}$ - and X-matrix. New PLS components are iteratively introduced until the systematic variation in the $\mathrm{Y}$-matrix has been exhausted.

Tools for evaluating the PLS models include correlation factors (R2Y), predictive powers (Q2), variable importance in the projection (VIP) plots, coefficient plots and weight vectors. The amount of the variance of the $\mathrm{Y}$-matrix described by the model is R2Y, which accordingly should be high (approaching 1). Q2 is the predictive power, an estimate of the reliability/stability of the model calculated by crossvalidation. In order to obtain a high predictive power, R2Y should be high. A value of Q2>0.9 is excellent, while a value above 0.5 is good. With non-significant components, Q2 can even be negative. The difference between R2Y and Q2 should be as low as possible and a difference larger than 0.2-0.3 may indicate outliers or the presence of irrelevant variables in the $X$ block. VIP plots present the importance of each parameter in the model with respect to its correlation to all the responses $(Y)$ and to the projection $(\mathrm{X})$, reflecting relative importance of the model parameters to each other (in absolute values). Parameters with high VIP values $(>1)$ are considered most relevant for explaining the responses. Coefficient plots illustrate contribution of the variables in the X-matrix to each individual response in the $\mathrm{Y}$-matrix and can for instance reflect how experimental variables and sediment properties affect remediation. Weight vectors, $\mathrm{w}^{*}(\mathrm{X}$-matrix) and $\mathrm{c}(\mathrm{Y}$-matrix), are introduced to show the contribution of each variable in $X$ to the description of the systematic variation in the $Y$ matrix [5].

In this study SimcaP11 software was used for PLS modelling based on the 47 experiments listed in table 2. The X-matrix consisted of the 6 experimental variables (time, time after acidification, current density, stirring rate, L/S ratio, suspension liquid and light/no light) (table 2 ) and sediment properties (element concentrations, chloride, TC, S, N, P, carbonate, organic matter, CEC, grain size distribution, $\mathrm{pH}$, conductivity) (table 1). The $\mathrm{Y}$-matrix consisted of the final concentrations of the elements $\mathrm{Al}, \mathrm{Ca}$, $\mathrm{Fe}, \mathrm{K}, \mathrm{Mg}, \mathrm{Mn}, \mathrm{Na}, \mathrm{Cr}, \mathrm{Cu}, \mathrm{Ni}, \mathrm{Pb}$ and $\mathrm{Zn}$.

\section{Results and discussion}

\subsection{Metal availability in the sediments}

It was previously found that of the seven analysed environmental priority metals $(\mathrm{As}, \mathrm{Cd}, \mathrm{Cr}, \mathrm{Cu}, \mathrm{Ni}, \mathrm{Pb}$ and $\mathrm{Zn}$ ), it was only $\mathrm{Cu}, \mathrm{Pb}$ and $\mathrm{Zn}$ that exceeded the environmental quality criteria from Arctic countries to an extent at which potential effects on the marine environment could occur [33]. For this reason, they remain the focus for the remediation in this study.

Metal partitioning, determined by sequential extraction, is an indication of how available the metals are in the sediment and to what extent a metal will be mobilised by ion-exchange, dissolution of carbonates, reducing or oxidising conditions, or acidic $(\mathrm{pH}<2)$ conditions. It can be a useful tool for assessing the potential for removing metals from sediments by electrodialysis and higher removal rates have for instance been observed for the more available metals (exchangeable/reducible) in the sediment $[7,30]$.

Metal partitioning of $\mathrm{Cu}, \mathrm{Pb}$ and $\mathrm{Zn}$ (figure 1) revealed that $\mathrm{Cu}$ is mostly found in the exchangeable and oxidisable fractions (>80\%), while $\mathrm{Pb}$ is mostly found in the exchangeable fraction, apart from the $\mathrm{H} 1$ 
sediment, in which a large fraction is bound to organic matter. $\mathrm{Zn}$ is mostly bound in the exchangeable fraction. Metals found in the residual fraction, the most difficult to mobilise are, apart from $\mathrm{Pb}$ in sediment S2, below 25\% indicating that there is potential for high removal rates by EDR in the sediments. Metals in the stable minerals may however also dissociate during EDR as previous studies showed acceleration in the weathering of the soil and changes in the availability of residual metal [36, 37].

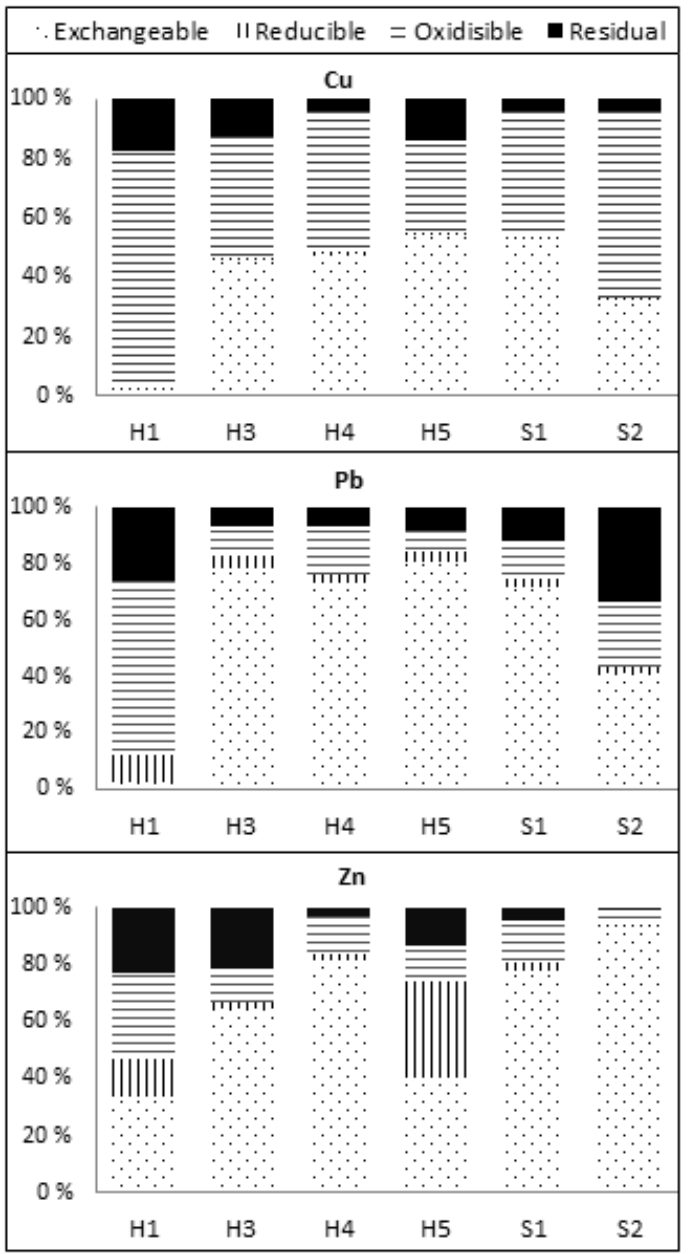

Figure 1: Metal partitioning of $\mathrm{Cu}, \mathrm{Pb}$ and $\mathrm{Zn}$ in the six harbour sediments. Exchangeable - metals mobilised by ion-exchange or by dissolution of carbonates; reducible - metals bound in Fe/Mn oxides, desorbing under anoxic conditions; oxidisable - metals bound in organic matter, desorbing during oxidation of organic matter; residual - remaining metals in the sediment.

Desorption of metals with nitric acid in different concentrations were performed to determine metal desorption as function of time to complement the metal partitioning findings. For $\mathrm{Cu}$ and $\mathrm{Pb}$, the desorption as function of $\mathrm{pH}$ were similar for the six sediments (figure 2 ) for $\mathrm{pH}$ values above 2 . At $\mathrm{pH}<2$, there were some deviations in the desorption, an indication that the sediment properties affected the binding/re-precipitation of desorbed $\mathrm{Cu}$ and $\mathrm{Pb}$ at acidic conditions. For $\mathrm{Zn}$, it was revealed that there were deviations in desorption patterns for $\mathrm{pH}<4$ suggesting that sediment properties, other than the buffer capacity was affecting the desorption/re-precipitation and binding of $\mathrm{Zn}$ in the sediment. 


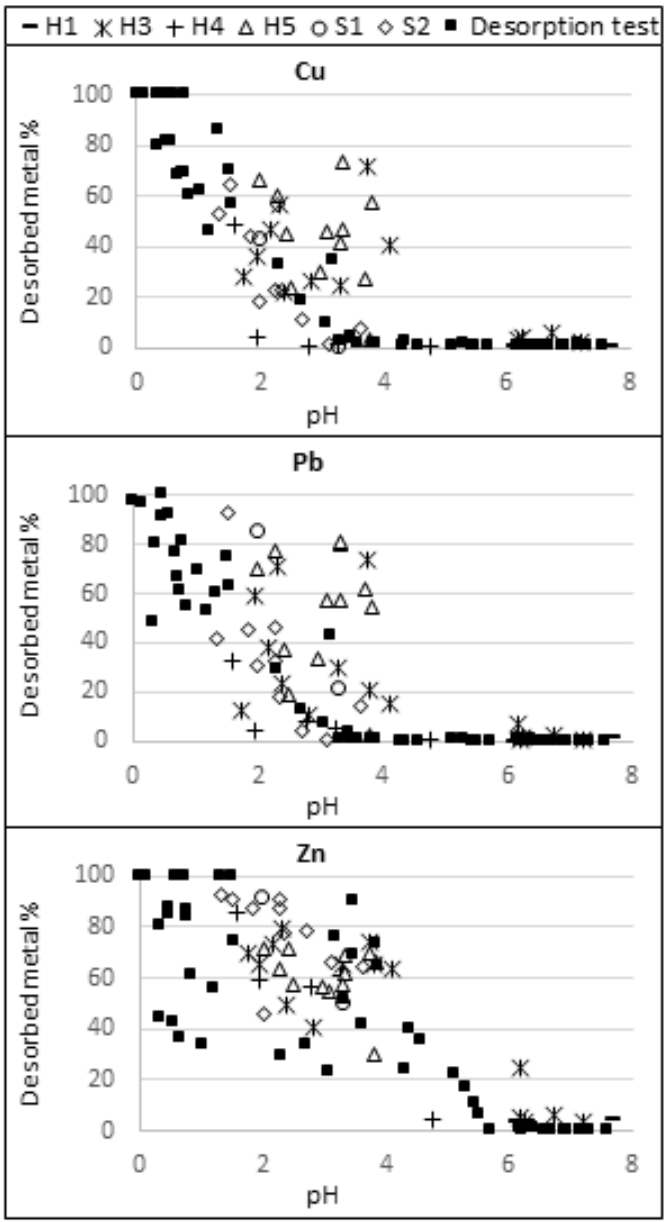

Figure 2: Desorption of $\mathrm{Cu}, \mathrm{Pb}$ and $\mathrm{Zn}$ from the six sediments as function of $\mathrm{pH}(\square)$, by acid treatment. Desorption of $\mathrm{Cu}, \mathrm{Pb}$ and $\mathrm{Zn}$ at the end of the electrodialytic experiments as function of final $\mathrm{pH}$ for the six sediments (H1, H3, H4, H5, S1 and S2).

At the end of the EDR experiments, higher desorption of $\mathrm{Cu}$ and $\mathrm{Pb}$ were observed at final $\mathrm{pH}$ values from 2-4, indicating a higher removal potential than for the nitric acid desorption tests (figure 2). A similar trend is observed for $\mathrm{Zn}$, although not as distinct. Comparison of the desorption tests with the percentage of metal desorbed at the end of the EDR experiments shows that higher desorption of $\mathrm{Cu}$ and $\mathrm{Pb}$ was observed in the $\mathrm{pH}$ range 2-4 indicating a higher removal potential than was expected from the desorption tests. The same trend is observed for $\mathrm{Zn}$ although not as distinct. None of the sediments appears to be correlated which indicate that other parameters (e.g. experimental variables) influence the mobilisation during EDR. In contrast to the findings of the nitric acid desorption experiments, it is apparent that higher desorption of metals during EDR was not dependent on continuously acidifying the sediment. By applying optimal experimental settings according to the sediment, it was possible to achieve high desorption of metals in the $\mathrm{pH}$ range 2-4.

\subsection{Variable importance for the acidification time during EDR}

In order to achieve more than $50 \%$ desorption of $\mathrm{Cu}, \mathrm{Pb}$ and $\mathrm{Zn}$ it is apparent from figure 2 that final $\mathrm{pH}$ should be below 4. With the aim of evaluating the influence of sediment properties and how to optimise the experimental settings for ensuring efficient acidification, a PLS model was calculated. The acidification time of the EDR experiments was computed as a single parameter in the Y-matrix and the model included experiments with final $\mathrm{pH}$ around $4(n=14)$. The PLS model had a correlation factor, 
$R^{2} Y$ of 0.87 and a predictive power $Q^{2}$ of 0.64 indicating a good and stable model. The parameters with highest influence on the model (VIP values $>1$ ) were sediment properties related to buffer capacity and grain size. The negative/positive correlations between variables and acidification time are revealed by coefficient values (figure 3 ). Sediments with high buffer capacity (high carbonate, $\mathrm{pH}$ ) prolongs the acidification time. $\mathrm{Ca}$ and $\mathrm{Mg}$ were found as carbonates in the sediments and this is the main reason for the positive correlation with acidification time. Sediments with higher contents of the fine grained fractions (clay, silt) resulted in longer acidification times and is due to the higher buffer capacity of clay/silt compared to sand [38].

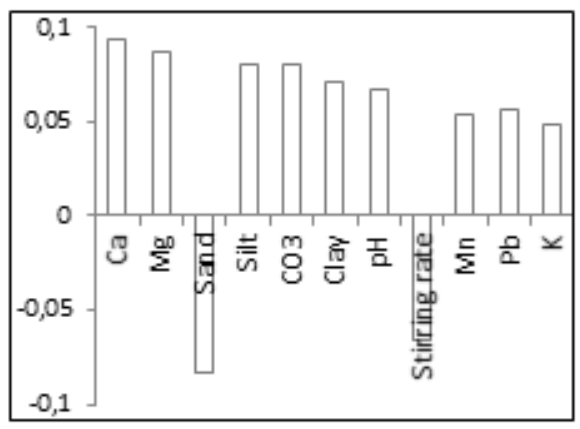

Figure 3: Coefficient plot of the PLS model on acidification time (final pH 4). The plot only shows the coefficients of the most important parameters (VIP values $>1$ ), as determined by the model. Parameters with coefficient values $<1$ have opposite correlation with acidification time, while parameters coefficient values $>1$ are positively correlated with acidification time.

The only experimental variable with a high influence on the model (VIP value $>1$ ) was stirring rate and the coefficient plot (figure 3 ) revealed that a high stirring rate decreased the acidification time. By applying a high stirring rate $(1300 \mathrm{rpm})$, the acidification times were in the range 19-163 $\mathrm{h}$, while applying a low stirring rate $(<100 \mathrm{rpm})$, the acidification times were in the range 142-672 $\mathrm{h}$ for the studied sediments. This accentuates the importance of achieving a fast, uniform acidification in the sediment suspension, achievable by increasing the stirring rate.

\subsection{Variable importance for metal removal during EDR}

A PLS model was calculated to evaluate the comparative influence of sediment properties and experimental settings on metal removal during EDR. The model, hereafter referred to as Model 1, was based on the 47 experiments listed in table 2 and included all measured elements as responses ( $\mathrm{Al}, \mathrm{Ca}$, $\mathrm{Fe}, \mathrm{K}, \mathrm{Mg}, \mathrm{Mn}, \mathrm{Na}, \mathrm{Cr}, \mathrm{Cu}, \mathrm{Ni}, \mathrm{Pb}$ and $\mathrm{Zn}$ ). The model correlation factor, $\mathrm{R}^{2} \mathrm{Y}$, was 0.82 and the predictive power, $\mathrm{Q}^{2}$, was 0.74 ; an indication of a good and stable model.

Table 3: Variable importance in Model $1\left(R^{2} Y 0.82 ; Q^{2} 0.74\right)$. Parameters with VIP values $>1$ had the highest influence on the model, parameters with VIP values 0.5-1 had mediocre influence on the model and parameters with VIP values $<0.5$ had low influence on the model.

\begin{tabular}{|l|l|l|l|l|}
\hline $\begin{array}{l}\text { VIP } \\
\text { value }\end{array}$ & $\begin{array}{l}\text { Experimental } \\
\text { variables }\end{array}$ & $\begin{array}{l}\text { Sediment } \\
\text { properties }\end{array}$ & $\begin{array}{l}\text { Trace } \\
\text { elements }\end{array}$ & Priority metals \\
\hline$>1$ & & $\begin{array}{l}\text { Grain size } \\
\text { S }\end{array}$ & $\begin{array}{l}\mathrm{Al}, \mathrm{Ca}, \mathrm{Fe}, \mathrm{K}, \\
\mathrm{Mg}, \mathrm{Mn}\end{array}$ & $\mathrm{Cr}, \mathrm{Cu}, \mathrm{Ni}, \mathrm{Pb}$ \\
\hline $0.5-1.0$ & $\begin{array}{l}\text { Time after } \mathrm{pH} 4 \\
\text { Stirring rate }\end{array}$ & $\begin{array}{l}\text { Carbonate } \\
\text { CEC } \\
\text { Organic matter } \\
\text { TC }\end{array}$ & & \\
& & TC & \\
\hline
\end{tabular}




\begin{tabular}{|l|l|l|l|l|}
\hline & & $\mathrm{N}$ & & \\
\hline$<0.5$ & $\begin{array}{l}\text { Total treatment time } \\
\text { Current density } \\
\text { L/S ratio } \\
\text { Suspension liquid } \\
\text { Light }\end{array}$ & $\mathrm{P}$ & $\mathrm{Cl}$ & $\mathrm{Na}$ \\
Conductivity & & & \\
\hline
\end{tabular}

A summary of the calculated VIP values in the model is given in table 3 and it is apparent that sediment properties were in general more important for EDR efficiency than the experimental settings, in line with previous investigations [10]. The grain size distribution as well as the initial content of metals had the highest influence on the model, indicating that the quantity and composition of elements in the sediment significantly influences EDR. A weight plot of the $X\left(w^{*}\right)$ and $Y(c)$ matrix of the first and second components (figure 4) reveals that the initial concentrations of some elements ( $\mathrm{Al}, \mathrm{Fe}, \mathrm{K}, \mathrm{Mg}$, $\mathrm{Mn}, \mathrm{Cr}, \mathrm{Ni}$ ) are plotted adjacent to the removal efficiencies of the same elements indicating that a high initial metal concentration results in lower removal.

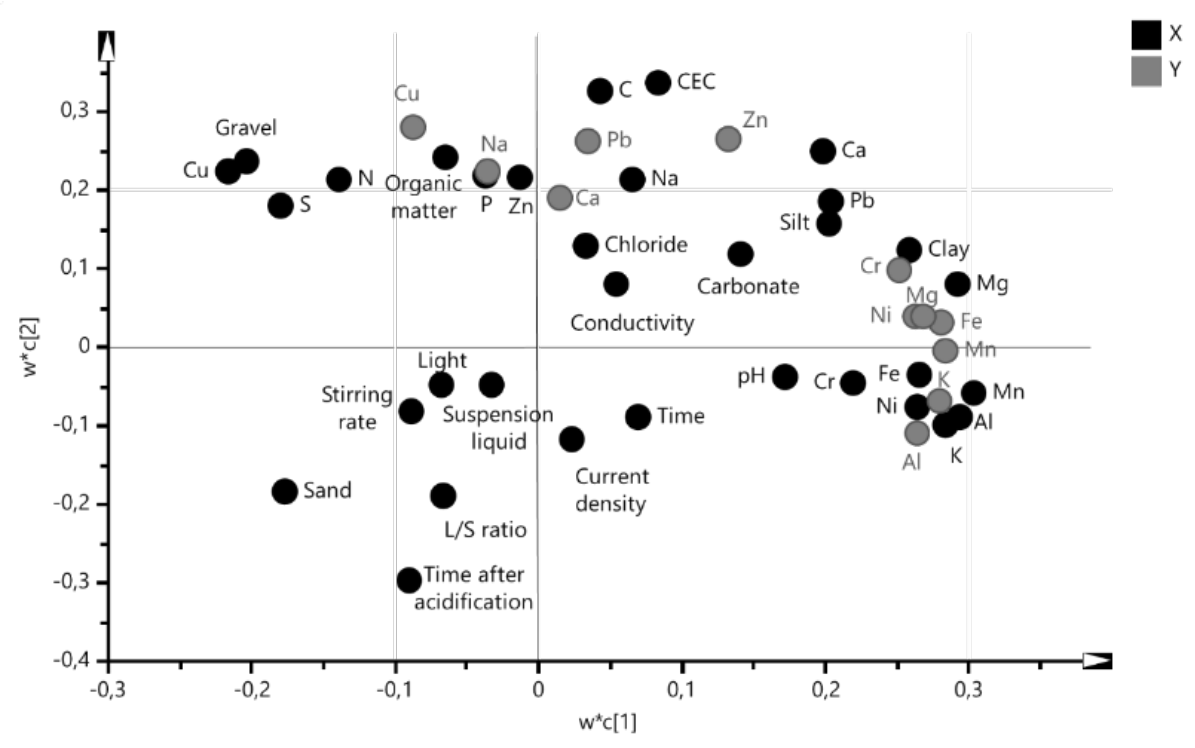

Figure 4: $X\left(w^{*}\right)$ and $Y(c)$ weights for the first and second component. Directly correlated $X$ and $Y$ variables are located adjacent to one another.

Model 1 was used to obtain a good overview of general trends and correlated variables and responses in the metal removal during EDR (figure 4). In order to assess possible differences in trends of the targeted metals, separate models were calculated for $\mathrm{Cu}, \mathrm{Pb}$ and $\mathrm{Zn}$ and included metal partitioning data for the three metals. In addition, a model was calculated for each phase of EDR to evaluate the differences in variable importance during EDR. Based on the EDR desorption trends in figure 2, the limited experimental domains have been selected based on the final $\mathrm{pH}$ values:

Model 2a: $\mathrm{pH}>4$ (experiments that were stopped during the lag phase of $\mathrm{Cu}, \mathrm{Pb}$ and $\mathrm{Zn}$ ); $\mathrm{n}=14$

Model 2b: $\mathrm{pH}$ 2-4 (experiments that were stopped during the fast removal phase of $\mathrm{Cu}, \mathrm{Pb}$ and $\mathrm{Zn}$ ); $\mathrm{n}=23$

Model 2c: $\mathrm{pH}<2$ (experiments that continued until the slow removal phase; towards/entering the stationary phase); 10 experiments 
The model correlation factors and predictive powers for all nine models were found to be good (figure 7) enabling evaluation of variable importance in the different phases of EDR. In general, sediment properties were found to be comparatively more significant than the experimental settings, in line with Model 1 findings. In the following, the variation in trends between the three metals and EDR phases will be assessed in the order experimental settings, sediment properties and metal partitioning.

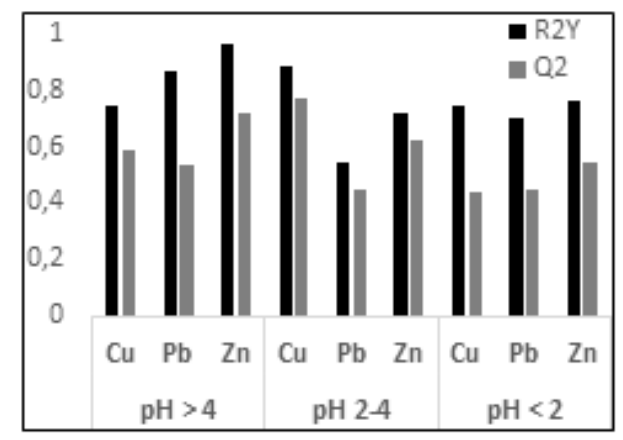

Figure 5: Correlation factors, $R^{2} Y$ and predictive powers, $Q^{2}$ for the models $2 a$ (experiments with final $p H>4$ ), $2 \mathrm{~b}$ (experiments with final $\mathrm{pH} 2-4$ ) and $2 \mathrm{c}$ (experiments with final $\mathrm{pH}<2$ ).

\subsubsection{Influence of experimental variables}

For models 2a-c, the variables suspension liquid and light/no light consistently had VIP values below 0.5 with limited influence on EDR. The total remediation time also had low VIP values in line with a previous study in which it was revealed that better PLS models could be achieved by experimental designs based on time after acidification rather than the total remediation time. The assessment of experimental variables and their influence on the metal removal during EDR is henceforth focused on the remaining experimental variables - time after acidification, current density, L/S ratio and stirring rate. As illustrated in figure 6 , similar trends for these variables were observed for $\mathrm{Cu}, \mathrm{Pb}$ and $\mathrm{Zn}$. 


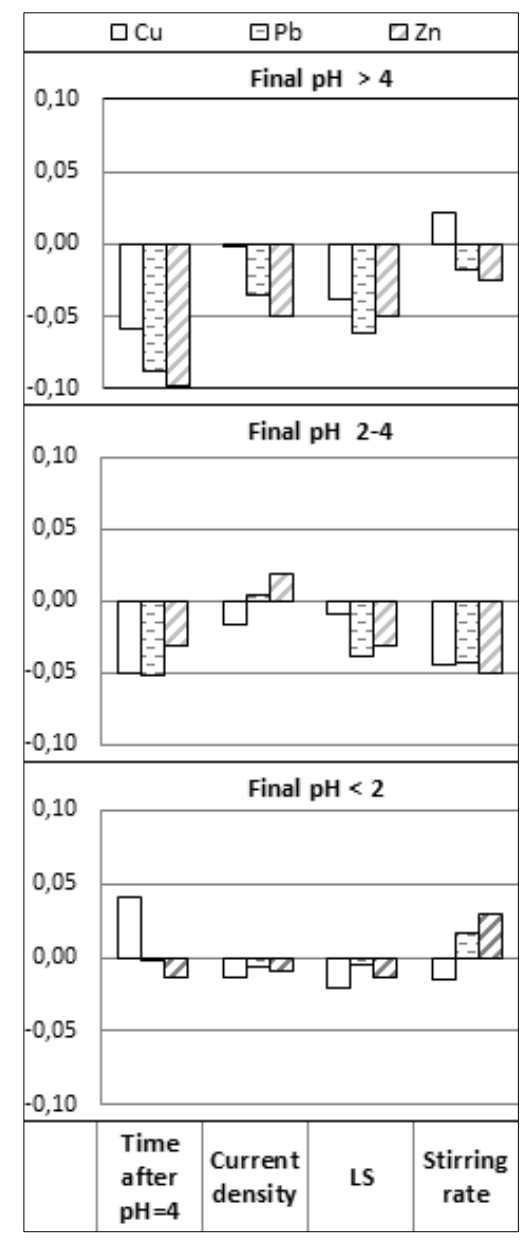

Figure 6: Coefficient plots of experimental variables for the separate PLS models of $\mathrm{Cu}, \mathrm{Pb}$ and $\mathrm{Zn}$ : Model $2 \mathrm{a}$ (experiments with final $\mathrm{pH}>4$ ), Model $2 \mathrm{~b}$ (experiments with final pH 2-4) and Model $3 \mathrm{~b}$ (experiments with final $\mathrm{pH}<2$ ).

For the experiments covering most of the initial lag phase of the three targeted metals (model 2a), time after acidification and the $\mathrm{L} / \mathrm{S}$ ratio were the most influential variables on the final concentrations of $\mathrm{Cu}, \mathrm{Pb}$ and $\mathrm{Zn}$. The coefficient plot in figure 6 reveals that low settings result in less efficient removal. The importance of the $\mathrm{L} / \mathrm{S}$ ratio may imply that relatively more removal from the available fractions occurs in this phase of EDR. It is also worth noting that the experimental variables are comparatively less important to the removal of $\mathrm{Cu}$. This may be related to a higher amount of $\mathrm{Pb}$ and $\mathrm{Zn}$ available for ion-exchange or dissolution in carbonates, in line with the results of the sequential extractions (figure 1).

For the experiments with final $\mathrm{pH}$ values $2-4$ (Model $2 \mathrm{~b}$ ), the stirring rate is comparatively more important than in the initial stage of EDR, and is similar to the influence of time after acidification. This may be an indication of the oxidation of sediments, in which some of the metals bound to organic matter are released and may also be related to higher stirring rates ensuring better mixing of the sediment suspension. For $\mathrm{Pb}$ and $\mathrm{Zn}$ the importance of the $\mathrm{L} / \mathrm{S}$ ratio is equivalent to time after acidification and stirring rate, indicating removal of $\mathrm{Pb}$ and $\mathrm{Zn}$ from the available fractions of the sediment, as was the case in the lag phase of EDR.

For the experiments with final pH below 2 (Model 2c) the comparative importance of the experimental variables on the removal of $\mathrm{Cu}, \mathrm{Pb}$ and $\mathrm{Zn}$ from the sediment are lower (figure 6). This may be related 
to the a lower difference in observed final concentrations of the metals than was the case for experiments with higher final $\mathrm{pH}$ and an indication of transition to the slow removal phase, in which removal may be relatively more dependent on sediment properties. This is due to lower availability caused by low concentration and tighter binding to the sediment.

\subsubsection{Influence of sediment properties}

In models 2a-c, all sediment properties had VIP values above 0.5 and are included in the discussion below. The sediment properties with highest influence on the removal of $\mathrm{Cu}, \mathrm{Pb}$ and $\mathrm{Zn}$ differed in the three phases of EDR (figure 7). High CEC resulted in low removal of $\mathrm{Cu}, \mathrm{Pb}$ and $\mathrm{Zn}$ and the influence of CEC is most distinct in the initial phase of EDR (figure 7). In Model 1 of all studied elements, other metals highly influenced by CEC (figure 4) included $\mathrm{Ca}$, $\mathrm{Na}$ and to a lesser degree $\mathrm{Mg}$. CEC had a higher influence on the removal of $\mathrm{Na}, \mathrm{Ca}, \mathrm{Pb}$ and $\mathrm{Zn}$, which have higher relative amounts bound in the exchangeable fractions compared to $\mathrm{Cu}$ and $\mathrm{Mg}$. These findings are in line with previous studies in which CEC of soil was shown to affect the efficiency of EKR $[39,40]$. Darmawan and Wada for instance found that longer time was necessary to remove metals from soils with high CEC [21].

The influence of conductivity is limited in the initial phases of EDR and in the slow removal phase affects the metals differently. In this phase, it is limited for the removal of $\mathrm{Cu}$, while it is significant for $\mathrm{Pb}$ and $\mathrm{Zn}$ (figure 7). Since an initial high conductivity in the sediment results in less removal of $\mathrm{Pb}$ and $\mathrm{Zn}$ in the later stage of EDR, this may imply that $\mathrm{Pb}$ and $\mathrm{Zn}$ are in the slow removal phase of EDR. This is further supported by amounts equivalent to exchangeable fractions being removed at this stage.

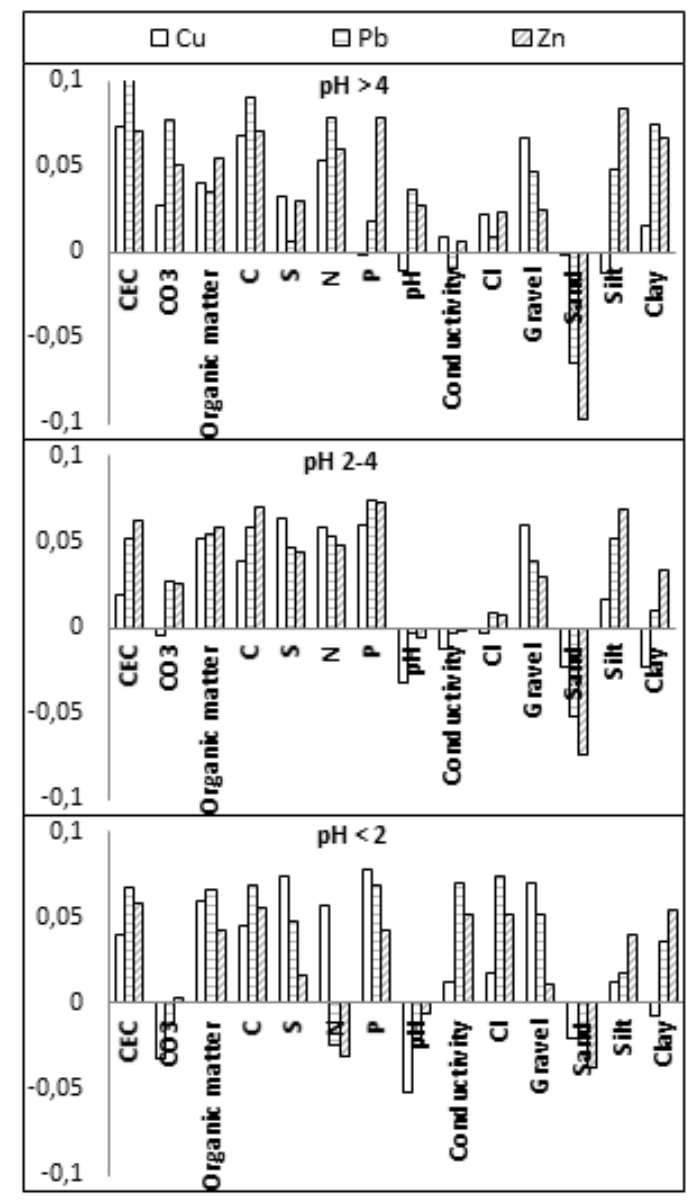


Figure 7: Coefficient plots of sediment properties for the separate PLS models of $\mathrm{Cu}, \mathrm{Pb}$ and $\mathrm{Zn}$ : Model 2a (experiments with final $\mathrm{pH}>4$ ), Model $2 \mathrm{~b}$ (experiments with final pH 2-4) and Model $3 \mathrm{~b}$ (experiments with final $\mathrm{pH}<2$ ).

The influence of the initial $\mathrm{pH}$ of the sediments is generally low, but is however relatively higher for the experiments with a final $\mathrm{pH}$ below 2, especially for $\mathrm{Cu}$. A low initial $\mathrm{pH}$ results in lower removal of $\mathrm{Cu}$ which is not necessarily related to the carbonaceous properties of the soil but to the release of $\mathrm{Cu}$ from the organic fraction (a low pH does not necessarily increase the release of $\mathrm{Cu}$ from the oxidisable fraction).

An initial high carbonate content results in low removal of $\mathrm{Cu}, \mathrm{Pb}$ and $\mathrm{Zn}$ in the initial phase of EDR confirming the influence of buffer capacity as reported in literature [41, 42]. Carbonate appears to have the opposite influence in the slow removal phase of $\mathrm{Cu}$ and $\mathrm{Pb}$ (figure 7) which could be related to the low difference in final concentration range, so further removal of any residual carbonate would result in relatively higher removal. This would also indicate that $\mathrm{Cu}$ and $\mathrm{Pb}$ to a higher degree are bound to carbonates in the sediment (initially or via co-precipitation) than $\mathrm{Zn}$.

Organic matter and components related to the organic matter; TC, S, N and $\mathrm{P}$ all highly influence the removal of $\mathrm{Cu}, \mathrm{Pb}$ and $\mathrm{Zn}$ in all phases of $\mathrm{EDR}$, in line with findings of organic matter influencing electrokientic remediation of marine sediments [43]. In this study, some differences in influence depending on the given heavy metal and the EDR phase were observed. Oxidation of the sediment, e.g. caused by stirring, is expected to release some of the metals bound in the oxidisable fraction, high content of the organic matter however still result in a low electrodialytic removal.

The initial content of chloride generally has a low influence on the removal of metals from the sediment. It is however noted that a high content of chloride appears to inhibit the removal of $\mathrm{Pb}$ and $\mathrm{Zn}$ in the experiments of final $\mathrm{pH}<2$. This may indicate complexation and co-precipitation with $\mathrm{Cl}$; this trend has however not been found in previous studies and further investigations of the specific influence of $\mathrm{Cl}$ on the EDR phases are necessary to confirm these observations.

Grain size distribution highly influences the EDR of $\mathrm{Cu}, \mathrm{Pb}$ and $\mathrm{Zn}$. A high content of gravel, silt and clay generally results in lower removal in all phases of EDR. This may not necessarily be contradictory to previous findings of higher removal efficiencies in soil fines than for the original soil [26] and may be due to more metals bound in the silt and clay fractions of the sediment. It could also be related to faster acidification of sediments with higher sand fractions (figure 3 ).

Of the 12 elements included in the $\mathrm{X}$ matrix of models $2 \mathrm{a}-2 \mathrm{c}, \mathrm{VIP}$ plots revealed that $\mathrm{Al}, \mathrm{K}, \mathrm{Mn}, \mathrm{Cu}$ and $\mathrm{Zn}$ had the highest influence on the removal of $\mathrm{Cu}$, while initial concentrations of $\mathrm{Ca}, \mathrm{Pb}$ and $\mathrm{Zn}$ were most influential for the removal of $\mathrm{Pb}$ and $\mathrm{Zn}$ (table 4). Coefficient plots showed differences in correlations between the initial content of elements and final concentrations of the three targeted metals (not shown). For $\mathrm{Cu}$, high concentrations of $\mathrm{Al}, \mathrm{K}$ and $\mathrm{Mn}$ resulted in lower final concentrations of $\mathrm{Cu}$, while high concentrations of $\mathrm{Cu}$ and $\mathrm{Zn}$ resulted in lower removal of $\mathrm{Cu}$. For $\mathrm{Pb}$ and $\mathrm{Zn}$, high initial concentrations of each element consistently resulted in relatively less removal. The high VIP values strongly indicate that the removal of $\mathrm{Cu}, \mathrm{Pb}$ and $\mathrm{Zn}$ depends on the initial element concentrations and may be inhibited high levels of certain elements, different from metal to metal. In the studied experimental space, elements mainly bound in the exchangeable fractions ( $\mathrm{Ca}, \mathrm{Pb}, \mathrm{Zn}$ and to a lesser degree $\mathrm{Mg}$ and $\mathrm{Na}$ ) for instance had an inhibitory effect on the removal of $\mathrm{Pb}$ and $\mathrm{Zn}$. These 
findings are in line with numerous reported studies on the inhibitory effect of elements and multiple metal contaminations on EDR/EKR efficiency summarised in [27].

Table 4: Summary of VIP values for elements (initial concentrations) in models $2 \mathrm{a}-\mathrm{c}$ for the removal of $\mathrm{Cu}, \mathrm{Pb}$ and $\mathrm{Zn}$. Parameters with values $>1$ had the highest influence on the model, parameters with VIP values 0.5-1 had mediocre influence on the model and parameters with VIP values $<0.5$ had low influence on the model.

\begin{tabular}{|l|l|l|l|}
\hline VIP value & $\mathrm{Cu}$ & $\mathrm{Pb}$ & $\mathrm{Zn}$ \\
\hline$>1$ & $\begin{array}{l}\mathrm{Al}, \mathrm{K}, \mathrm{Mn} \\
\mathrm{Cu}, \mathrm{Zn}\end{array}$ & $\begin{array}{l}\mathrm{Ca} \\
\mathrm{Cu}, \mathrm{Pb}, \mathrm{Zn}\end{array}$ & $\begin{array}{l}\mathrm{Ca} \\
\mathrm{Pb}, \mathrm{Zn}\end{array}$ \\
\hline $0.5-1.0$ & $\begin{array}{l}\mathrm{Ca}, \mathrm{Fe}, \mathrm{Mg}, \mathrm{Na} \\
\mathrm{Cr}, \mathrm{Ni}\end{array}$ & $\mathrm{Mg}, \mathrm{Na}$ & $\begin{array}{l}\mathrm{Fe}, \mathrm{K}, \mathrm{Mg}, \mathrm{Na} \\
\mathrm{Cr}, \mathrm{Cu}, \mathrm{Ni}\end{array}$ \\
\hline$<0.5$ & $\mathrm{~Pb}$ & $\begin{array}{l}\mathrm{Al}, \mathrm{Fe}, \mathrm{K}, \mathrm{Mn} \\
\mathrm{Cr}, \mathrm{Ni}\end{array}$ & $\mathrm{Al}, \mathrm{Mn}$ \\
\hline
\end{tabular}

\subsubsection{Influence of metal partitioning}

Metal partitioning of the targeted heavy metal in the individual models $2 a-2 c$ yield VIP values in the range $0.61-1.33$, indicating that how the metals are chemically bound in the sediment highly influences the efficiency of EDR, building on previous findings of metal partitioning influencing the mobilisation of metals during electrokinetic remediation [44, 45]. Coefficient plots of Cu removal (figure 8) reveals similar correlations in metal partitioning during all phases of EDR. The influence of metal partitioning on the removal of $\mathrm{Pb}$ and $\mathrm{Zn}$ differs in the three phases of EDR (figure 8). Higher relative amounts of $\mathrm{Pb}$ bound in the exchangeable and reducible fractions in general increase the removal efficiencies of $\mathrm{Pb}$ with variations in importance between the three EDR phases. In the initial phases of EDR, the removal of $\mathrm{Zn}$ does not improve significantly with higher amounts bound in the available fractions. Increasing removal efficiencies appear to depend on differences in binding to the reducible and oxidisable fractions, suggesting that $\mathrm{Zn}$ bound in the oxidisable fraction is released at this stage. 


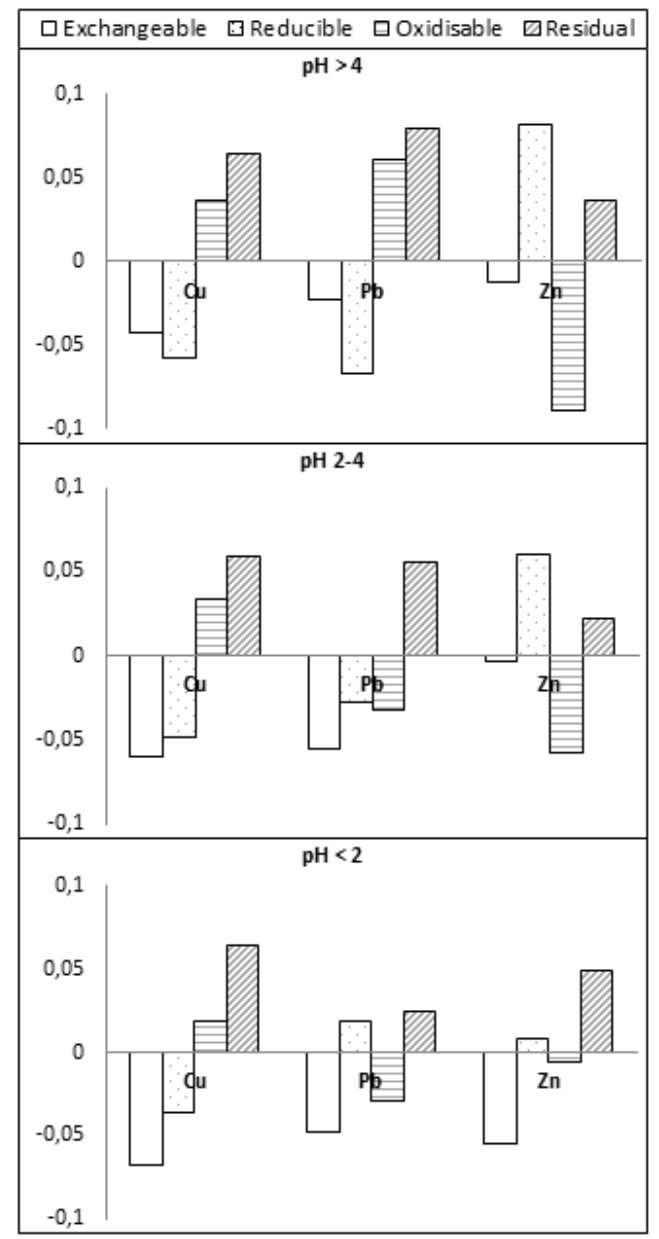

Figure

8: Coefficient plots of sediment properties for the separate PLS models of $\mathrm{Cu}, \mathrm{Pb}$ and $\mathrm{Zn}$ : Model $2 \mathrm{a}$ (experiments with final $\mathrm{pH}>4$ ), Model $2 \mathrm{~b}$ (experiments with final $\mathrm{pH}$ 2-4) and Model $3 \mathrm{~b}$ (experiments with final $\mathrm{pH}<2$ ).

The difference in trends of metal partitioning influence of $\mathrm{Pb}$ and $\mathrm{Zn}$ may indicate that removal occurs from all fractions of the sediment during EDR, as observed in previous studies [37, 46]. For Cu the influence of metal partitioning clearly indicates that removal is easier from the exchangeable and reducible fractions and may be removed from the exchangeable, reducible, oxidisable and residual fractions in that order to a higher degree than is the case for $\mathrm{Pb}$ and $\mathrm{Zn}$.

\section{Conclusion}

Sediment properties were found important for deciding experimental settings for optimal removal of metals during EDR, i.e. removal of $>75 \% \mathrm{Cu},>90 \% \mathrm{~Pb}$ and $>90 \% \mathrm{Zn}$. Variable importance differed in the different EDR phase for the targeted metals, $\mathrm{Cu}, \mathrm{Pb}$ and $\mathrm{Zn}$. In all phases of EDR important parameters, with VIP values $>1$, for the removal of $\mathrm{Cu}, \mathrm{Pb}$ and $\mathrm{Zn}$ included initial element concentration, grain size distribution and metal partitioning. The influence of elements depended on the targeted heavy metal, e.g. high concentrations of $\mathrm{Al}(8,000-8,650 \mathrm{mg} / \mathrm{kg})$ was found to increase $\mathrm{Cu}$ removal, while high concentrations of $\mathrm{Ca}(1400 \mathrm{~g} / \mathrm{kg}$ ) were found to inhibit the removal of $\mathrm{Pb}$ and $\mathrm{Zn}$.

In addition to the aforementioned parameters, other important sediment properties, with VIP values $>1$, in the lag phase of EDR (final $\mathrm{pH}>4$ ) included CEC and carbonate content, both related to the buffer capacity of the sediments with high contents inhibiting removal of metals. In the fast removal phase 
of EDR (final pH 2-4), organic matter was important along with stirring rate reflecting that oxidation of the sediment was important in order to mobilise metals bound in organic matter. In the slow removal phase of EDR, important sediment properties included organic matter (contents higher than 10\% inhibiting the removal) and conductivity. High contents of chloride ( $>9000 \mathrm{mg} / \mathrm{kg}$ ) appears to have significant inhibiting effect on the removal of $\mathrm{Pb}$ and $\mathrm{Zn}$ suggesting that complexation occurs. The experimental variables had VIP values less than 1 , much lower than the important sediment properties, indicating that EDR had entered in the slow removal phase in which chemical/physical properties are significantly more important for further removal of heavy metals from the sediment.

Variables related to the buffer capacity of the sediments and grain size distributions were found to highly influence the time for the sediments to reach $\mathrm{pH} 4$. High contents of sand (70\%) and low content of carbonate $(<2 \%)$ reduced the acidification time. Stirring rate also had a significant influence on the acidification time stressing the importance of thorough mixing (>700 rpm) of the sediment suspension to achieve a fast and uniform acidification.

\section{Acknowledgements}

The Northern Environmental Waste Management (EWMA) project, which is funded by the Research Council of Norway through NORDSATSNING (grant number 195160) and Eni Norge AS, is acknowledged for funding.

\section{References}

[1] R. Carlson, J.E. Carlson, Chapter 17 strategies for the selection of test systems, in: C. Rolf, E.C. Johan (Eds.) Data Handling in Science and Technology, Elsevier2005, pp. 403-424.

[2] S. Wold, M. Sjöström, L. Eriksson, PLS-regression: a basic tool of chemometrics, Chemometrics and intelligent laboratory systems, 58 (2001) 109-130.

[3] J. Trygg, S. Wold, Orthogonal projections to latent structures (O-PLS), Journal of Chemometrics, 16 (2002) 119-128.

[4] H. Abdi, Partial least squares regression and projection on latent structure regression (PLS Regression), Wiley Interdisciplinary Reviews: Computational Statistics, 2 (2010) 97-106.

[5] S. Jansson, R. Grabic, Multivariate relationships between molecular descriptors and isomer distribution patterns of PCBs formed during household waste incineration, Environmental Science and Pollution Research, 21 (2014) 3082-3090.

[6] S. Jonsson, Y. Persson, S. Frankki, B. van Bavel, S. Lundstedt, P. Haglund, M. Tysklind, Degradation of polycyclic aromatic hydrocarbons (PAHs) in contaminated soils by Fenton's reagent: a multivariate evaluation of the importance of soil characteristics and PAH properties, Journal of hazardous materials, 149 (2007) 86-96.

[7] K.B. Pedersen, P.E. Jensen, L.M. Ottosen, T. Lejon, An optimised method for electrodialytic removal of heavy metals from harbour sediments, Electrochimica Acta, 173 (2015) 432-439.

[8] K.B. Pedersen, T. Lejon, P.E. Jensen, L.M. Ottosen, Simultaneous electrodialytic removal of PAH, PCB, TBT and heavy metals from sediments, Journal of Environmental Management, 198, Part 1

(2017) 192-202.

[9] K.B. Pedersen, T. Lejon, P.E. Jensen, L.M. Ottosen, Applying multivariate analysis as decision tool for evaluating sediment-specific remediation strategies, Chemosphere, 151 (2016) 59-67.

[10] K.B. Pedersen, L.M. Ottosen, P.E. Jensen, T. Lejon, Comparison of 2-compartment, 3compartment and stack designs for electrodialytic removal of heavy metals from harbour sediments, Electrochim Acta, 181 (2015). 
[11] K.B. Pedersen, G.M. Kirkelund, L.M. Ottosen, P.E. Jensen, T. Lejon, Multivariate methods for evaluating the efficiency of electrodialytic removal of heavy metals from polluted harbour sediments, J Hazard Mater, 283 (2015).

[12] L.M. Ottosen, H.K. Hansen, S. Laursen, A. Villumsen, Electrodialytic remediation of soil polluted with copper from wood preservation industry, Environ Sci Technol, 31 (1997) 1711-1715.

[13] A.B. Ribeiro, E.P. Mateus, L.M. Ottosen, G. Bech-Nielsen, Electrodialytic removal of $\mathrm{Cu}, \mathrm{Cr}$, and As from chromated copper arsenate-treated timber waste, Environ Sci Technol, 34 (2000) 784-788.

[14] A.J. Pedersen, L.M. Ottosen, A. Villumsen, Electrodialytic removal of heavy metals from different fly ashes - Influence of heavy metal speciation in the ashes, J Hazard Mater, 100 (2003) 65-78.

[15] M.R. Jakobsen, J. Fritt-Rasmussen, S. Nielsen, L.M. Ottosen, Electrodialytic removal of cadmium from wastewater sludge, J Hazard Mater, 106 (2004) 127-132.

[16] G.M. Nystroem, L.M. Ottosen, A. Villumsen, Acidification of harbor sediment and removal of heavy metals induced by water splitting in electrodialytic remediation, Separ Sci Technol, 40 (2005) 2245-2264.

[17] Y.B. Acar, A.N. Alshawabkeh, Principles of Electrokinetic Remediation, Environ Sci Technol, 27 (1993) 2638-+.

[18] Y.B. Acar, R.J. Gale, A.N. Alshawabkeh, R.E. Marks, S. Puppala, M. Bricka, R. Parker, Electrokinetic Remediation - Basics and Technology Status, J Hazard Mater, 40 (1995) 117-137.

[19] A.N. Alshawabkeh, Electrokinetic Soil Remediation: Challenges and Opportunities, Separ Sci Technol, 44 (2009) 2171-2187.

[20] P.E. Jensen, L.M. Ottosen, C. Ferreira, A. Villumsen, Kinetics of electrodialytic extraction of Pb and soil cations from a slurry of contaminated soil fines, J Hazard Mater, 138 (2006) 493-499.

[21] Darmawan, S.I. Wada, Effect of clay mineralogy on the feasibility of electrokinetic soil decontamination technology, Applied Clay Science, 20 (2002) 283-293.

[22] K.-J. Kim, D.-H. Kim, J.-C. Yoo, K. Baek, Electrokinetic extraction of heavy metals from dredged marine sediment, Separation and Purification Technology, 79 (2011) 164-169.

[23] Y.B. Acar, A.N. Alshawabkeh, R.J. Gale, Fundamentals of extracting species from soils by electrokinetics, Waste Manage, 13 (1993) 141-151.

[24] G.M. Nystrom, L.M. Ottosen, A. Villumsen, Test of experimental set-ups for electrodialytic removal of $\mathrm{Cu}, \mathrm{Zn}, \mathrm{Pb}$ and $\mathrm{Cd}$ from different contaminated harbour sediments, Eng Geol, 77 (2005) 349-357.

[25] P.E. Jensen, L.M. Ottosen, C. Ferreira, Electrodialytic remediation of soil fines ( $<63 \mathrm{mu} \mathrm{m}$ ) in suspension - Influence of current strength and L/S, Electrochim Acta, 52 (2007) 3412-3419.

[26] T.R. Sun, L.M. Ottosen, P.E. Jensen, G.M. Kirkelund, Electrodialytic remediation of suspended soil - Comparison of two different soil fractions, Journal of Hazardous Materials, 203-204 (2012) 229235.

[27] K.-W. Kim, K.-Y. Lee, S.-O. Kim, Electrokinetic Remediation of Mixed Metal Contaminants, Electrochemical Remediation Technologies for Polluted Soils, Sediments and Groundwater, John Wiley \& Sons, Inc.2009, pp. 285-313.

[28] K.B. Pedersen, G.M. Kirkelund, L.M. Ottosen, P.E. Jensen, T. Lejon, Multivariate methods for evaluating the efficiency of electrodialytic removal of heavy metals from polluted harbour sediments, J Hazard Mater, 283 (2015) 712-720.

[29] G.M. Kirkelund, L.M. Ottosen, A. Villumsen, Electrodialytic remediation of harbour sediment in suspension-Evaluation of effects induced by changes in stirring velocity and current density on heavy metal removal and pH, J Hazard Mater, 169 (2009) 685-690.

[30] K.B. Pedersen, T. Lejon, L.M. Ottosen, P.E. Jensen, Screening of variable importance for optimizing electrodialytic remediation of heavy metals from polluted harbour sediments, Environ Technol, 36 (2015).

[31] L.M. Ottosen, P.E. Jensen, G.M. Kirkelund, C.D. Ferreira, H.K. Hansen, Electrodialytic Remediation of Heavy Metal Polluted Soil - treatment of water saturated or suspended soil, Chemical Engineering Transactions, 28 (2012) 103-108. 
[32] G.M. Nystroem, L.M. Ottosen, A. Villumsen, Electrodialytic removal of $\mathrm{Cu}, \mathrm{Zn}, \mathrm{Pb}$, and $\mathrm{Cd}$ from harbor sediment: Influence of changing experimental conditions, Environ Sci Technol, 39 (2005) 2906-2911.

[33] K. Pedersen, T. Lejon, P. Jensen, L. Ottosen, Chemometric analysis for pollution source assessment of harbour sediments in arctic locations, Water Air Soil Pollut, 226 (2015).

[34] G. Rauret, J.F. Lopez-Sanchez, A. Sahuquillo, R. Rubio, C. Davidson, P. Quevauviller, Improvement of the BCR three step sequential extraction procedure prior to the certification of new sediment and soil reference materials, J Environ Monitor, 1 (1999) 57-61.

[35] R. Parés Viader, P.E. Jensen, L.M. Ottosen, Electrodialytic remediation of municipal solid waste incineration residues using different membranes, Chemosphere, 169 (2017) 62-68.

[36] A.B. Ribeiro, A. Villumsem, A. Refega, J. Vieira e Silva, G. Bech-Nielsen, Looking at each step of a sequential extraction procedure applied to a contaminated soil before and after an electrodialytic remediation experiment, 16th World Congress of Soil ScienceMontpeiller, 1998.

[37] G.M. Kirkelund, L.M. Ottosen, A. Villumsen, Investigations of $\mathrm{Cu}, \mathrm{Pb}$ and $\mathrm{Zn}$ partitioning by sequential extraction in harbour sediments after electrodialytic remediation, Chemosphere, 79 (2010) 997-1002.

[38] Y.-Y. Liu, Y.-S. Zhao, J. Dong, P. Liu, Z.-G. Zhu, Y. Sun, [pH buffering capacity of geological media on landfill leachate], Huan Jing Ke Xue, 29 (2008) 1948-1954.

[39] R. Lageman, W. Pool, Experiences With Field Applications of Electrokinetic Remediation, Electrochemical Remediation Technologies for Polluted Soils, Sediments and Groundwater, John Wiley \& Sons, Inc.2009, pp. 697-717.

[40] S.I. Wada, Y. Umegaki, Major ion and electrical potential distribution in soil under electrokinetic remediation, Environ Sci Technol, 35 (2001) 2151-2155.

[41] M. Masi, R. Iannelli, G. Losito, Ligand-enhanced electrokinetic remediation of metalcontaminated marine sediments with high acid buffering capacity, Environmental Science and Pollution Research, 23 (2016) 10566-10576.

[42] M. Masi, A. Ceccarini, R. Iannelli, Model-based optimization of field-scale electrokinetic treatment of dredged sediments, Chemical Engineering Journal, 328 (2017) 87-97.

[43] M. Pazos, O. Iglesias, J. Gómez, E. Rosales, M.A. Sanromán, Remediation of contaminated marine sediment using electrokinetic-Fenton technology, Journal of Industrial and Engineering Chemistry, 19 (2013) 932-937.

[44] G. De Gioannis, A. Muntoni, A. Polettini, R. Pomi, Enhanced electrokinetic treatment of different marine sediments contaminated by heavy metals, Journal of Environmental Science and Health, Part A, 43 (2008) 852-865.

[45] R. Iannelli, M. Masi, A. Ceccarini, M.B. Ostuni, R. Lageman, A. Muntoni, D. Spiga, A. Polettini, A. Marini, R. Pomi, Electrokinetic remediation of metal-polluted marine sediments: experimental investigation for plant design, Electrochimica Acta, 181 (2015) 146-159.

[46] H. Wang, T. Liu, S. Feng, W. Zhang, Metal removal and associated binding fraction transformation in contaminated river sediment washed by different types of agents, PloS one, 12 (2017) e0174571. 